\title{
A young man with constitutional symptoms and a small bowel vegetating lesion
}

Um jovem com sintomas constitucionais e uma lesão vegetante em intestino delgado

Pedro Grachinski Buiar', Gustavo Cartaxo de Lima Gossling', Gilberto Schwartsmann'

\begin{abstract}
Gastrointestinal neuroectodermal tumor is a rare neoplasm that affects young population and is associated with poor prognosis. Previously named Clear cell sarcoma-like tumor of the gastrointestinal tract, due to the similar phenotypic pattern, advances in the molecular characterization of this tumor helped to differentiate it as a separate disease. Despite this, the small number of cases reported only suggests a reserved prognosis and isolated treatment recommendations based on local experiences. This case report illustrates a 37-year-old patient with constitutional symptoms diagnosed with metastatic disease treated with an aggressive approach involving preoperative chemotherapy followed by metastasis resection, with no evidence of disease recurrence after two years of follow-up.
\end{abstract}

Keywords: Neuroectodermal; Gastrointestinal; Rare; Young; Clear cell sarcoma

\begin{abstract}
RESUMO
O Tumor neuroectodérmico gastrintestinal é uma neoplasia rara, caracterizada por acometer pacientes jovens e possuir comportamento agressivo. Antigamente classificado como tumor gastrintestinal similar ao sarcoma de células claras, devido ao padrão fenotípico, os avanços na caraterização molecular deste tumor ajudaram a diferenciá-lo como uma entidade própria. Apesar disso, a pequena quantidade de casos relatados até hoje apenas sugerem uma prognostico reservado e trazem esquemas de tratamento baseados em poucos casos/experiências locais. Este relato de caso ilustra um paciente de 37 anos com sintomas sistêmicos, diagnosticado com doença metastática tratado com abordagem agressiva envolvendo ressecção das metástases e quimioterapia citotóxica pré-operatória, sem evidência de progressão de doença após dois anos de follow-up.
\end{abstract}

Descritores: Neuroectodérmico; Gastrointestinal; Raro; Jovem; Sarcoma de células claras

1. Hospital de Clínicas de Porto Alegre, Department of Medical Oncology - Porto Alegre - Rio Grande do Sul - Brazil

Financial support: No.

Conflicts of interest: No.

Correspondence author: Pedro Grachinski Buiar. Hospital de Clínicas de Porto Alegre, Department of Medical Oncology - Porto Alegre - Rio Grande do Sul - Brazil

R. Ramiro Barcelos, 2350 - Santa Cecilia, Porto Alegre - RS, 90035-007.

E-mail: pgbuiar@gmail.com / pbuiar@hcpa.edu.br 


\section{INTRODUCTION}

The malignant gastrointestinal neuroectodermal tumor (GNET), previously known as clear cell sarcoma-like tumor of the gastrointestinal tract, is a rare and recently recognized disease with an aggressive clinical course and early metastatic spread ${ }^{1-3}$. It was firstly recognized as a distinct clinical and morphological entity by Zanbrano et al in 2003', and the histologic differential diagnosis includes gastrointestinal stromal tumor (GIST) and malignant peripheral nerve sheath tumor (MPNST).

Microscopically, GNET is characterized by round cells with an epithelioid pattern and irregular nuclear contour that may grow with pseudo papillary and nest formation. The presence of osteoclast-like multinucleated giant cells seems to be a consistently described feature. Positive staining for S-100 and SOX10 as well as absence of staining for melanocytic markers (HMB45, melan-A) are typical. Epithelial markers, tyrosinase, $C D$ 117, SMA, CD 34 and DOG-1 are usually negative ${ }^{4}$.
A previously recognized translocation pattern of EWSR1(22q12) and CREB1(2q32.3) genes resulting in the fusion gene EWSR1-CREB1 was described in both GNET and clear cell sarcoma of the gastrointestinal tract ${ }^{5}$. Despite sharing this genetic abnormality, GNET has a more aggressive course of disease and lacks melanocytic differentiation, what suggests a different clinical entity from clear cell sarcoma of gastrointestinal tract, which typically stains positive for melanocytic differentiation markers (HMB45, Melan-A and MiTF).

Malignant gastrointestinal neuroectodermal tumor is more commonly diagnosed in young patients and is usually located in the small bowel, but can develop in any gastrointestinal segment. Vague abdominal pain and weight loss are common and some cases were diagnosed after mechanical small bowel obstruction secondary to a vegetating primary lesion $^{6,7}$.

\section{CASE PRESENTATION}

A 37-year old farmworker presented with a six month history of night sweats, fever and weight loss $(12 \mathrm{Kg})$. No other abnormalities at physical examination. Laboratory work-up revealed hypochromic microcytic anemia and atypical peripheral lymphocytes. CT scans showed presence of homogeneous hepatomegaly and enlarged mesenteric lymph nodes. Colonoscopy and upper GI endoscopy were unremarkable. Bone marrow aspiration/biopsy showed hyperplastic hematopoiesis and presence of increased plasma cells and histiocytes. Immunophenotypic studies revealed no anomalous cell populations. CT-guided biopsy of a mesenteric lymph node demonstrated reactive lymphoid hyperplasia. A CT enterography revealed a $4.5 \mathrm{~cm}$ long asymmetric parietal thickening of terminal ileum with an associated vegetating lesion and multiple enlarged lymph nodes(Figure 1).

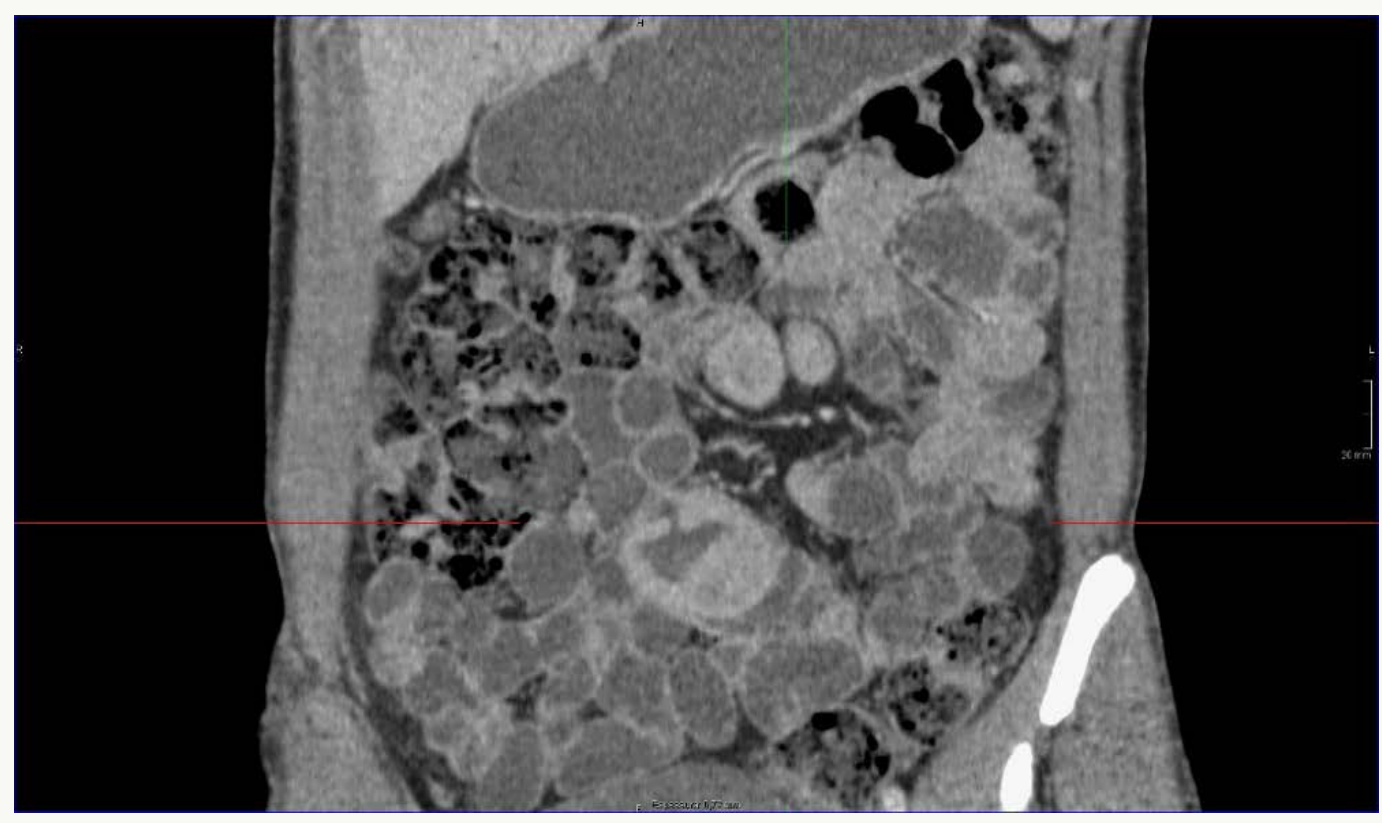

Figure 1. Small-bowell vegetating lesion 
An enterectomy plus lymphadenectomy was performed and a suspicious hepatic nodule discovered during surgery was excised. Anatomopathological examination revealed a poorly differentiated carcinoma with rare pleomorphic cells, high mitotic count and foci of necrosis, present in the primary lesion and the $5 \mathrm{~cm}$ lymph node and liver metastasis. Immunohistochemistry was positive for S100, SOX10 and AE1/AE3 and negative for CK7, CK20, Chromogranin, CD 56, TTF-1, Synaptophysin, CDX2, Tirosinase, Desmin, Melan A, CD45, Alpha SMA and CD34 (figure 2). The pathologist final report was Malignant gastrointestinal neuroectodermal tumor (GNET).

Following surgery a magnetic resonance imaging (MRI) was performed, revealing five other suspicious hepatic lesions (largest one with $1.9 \mathrm{~cm}$ ) and a $2.1 \mathrm{x}$
$1.6 \mathrm{~cm}$ mesenteric lymph node. A performed positron emission tomography-computed tomography (FDG/PET-CT; Figure 3) showed increased metabolic activity in the mesenteric node (standardized uptake value [SUV], 5.1) and in only two of five hepatic nodules, in transition of segments IVIVIII (SUV, 3.5) and VI/VII (SUV, 3.6).

After tumor board discussions, it was decided to perform neoadjuvant chemotherapy with four cycles of doxorubicin $75 \mathrm{mg} / \mathrm{m}^{2} \mathrm{D} 1$ + ifosfamide $1.8 \mathrm{~g} /$ $\mathrm{m}^{2}$ D1-D5 with mesna at 21-day intervals. Treatment was well tolerated. Following the completion of chemotherapy, a new MRI examination was performed, confirming stable disease. The patient underwent surgical resection of mesenteric lymph nodes and five liver metastases. All lesions removed confirm the diagnosis of GNET.
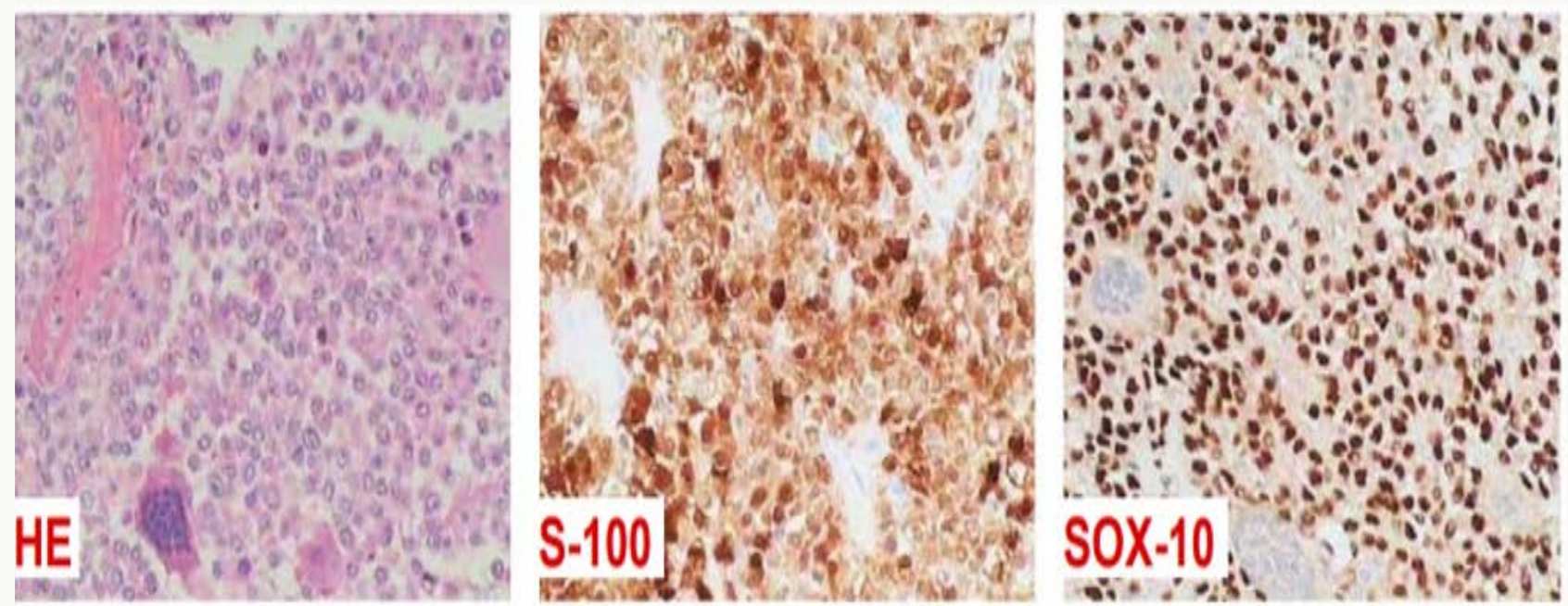

Figure 2. Immunohistochemical markers

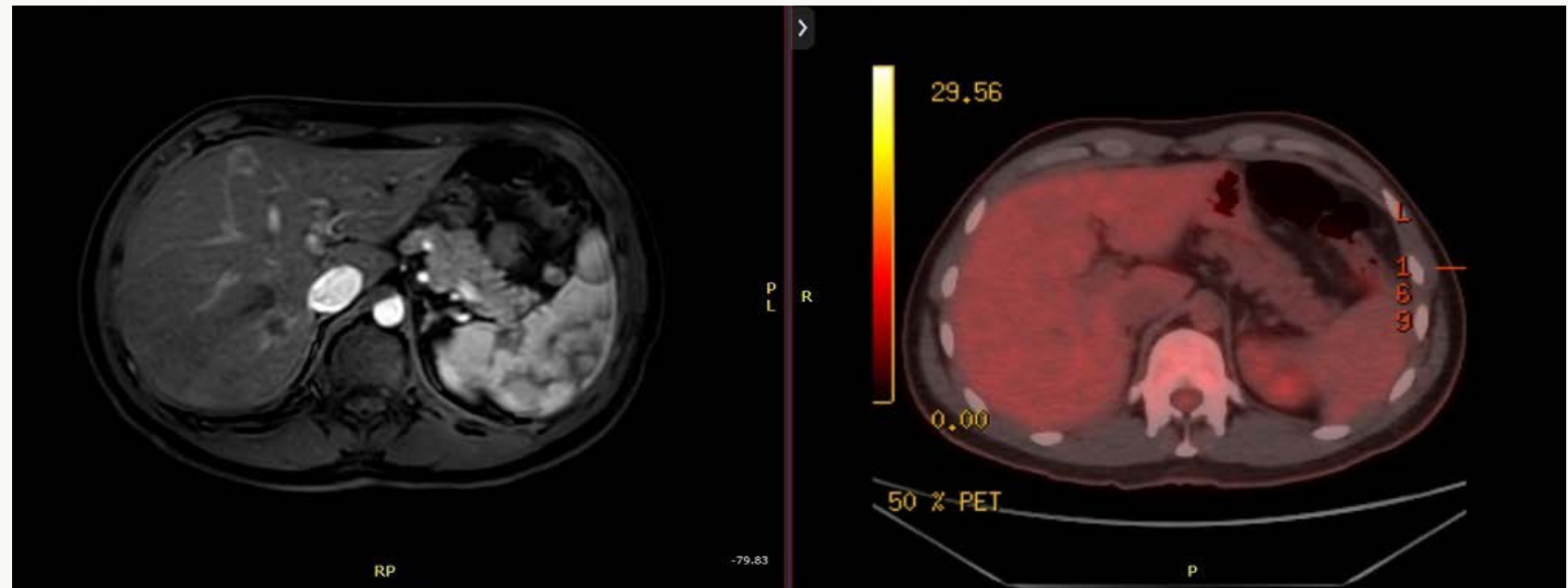

Figure 3. The erratic FDG uptake pattern of PET/CT in GNET 


\section{DISCUSSION}

Due to the rarity of GNET, there are no clear guidelines for its management and follow up. The cornerstone seems to be complete surgical resection. Despite this, and based on a limited number of cases reported in the literature (58 cases until 2018), GNET has a high rate of recurrence even after $\mathrm{RO}$ resection with $46.6 \%$ of patients developing metastasis ${ }^{8}$. As an example, Stockman et al. reported that of 12 patients with GNET only 2 were disease-free within 41 months $^{9}$. The revised median overall survival of patients with GNET reported in literature is only approximately 9.5 months. ${ }^{8}$,. The patient reported in this article is his third year alive after the diagnosis and his metastatic disease was managed with an aggressive approach with double regimen chemotherapy plus surgical resection of all possible sites of disease. Following complete tumor resection, there are no clear recommendations for the use of adjuvant treatment.

As an orphan disease, there is no consolidated data on the use of systemic treatment for metastatic disease. A difficulty in the management of rare cancers is the less scientific consideration and support in clinical research. The problem starts earlier in statistics, where to obtain a sufficient power of outcome analysis, a study of this population would require an unrealistic large sample-size. In current practice, oncologists also face the challenges of late diagnosis, difficulties in pathology confirmation of disease and definition of the best therapeutic strategies. In developing countries, with scarce resources regarding genetic analyses, and difficulties in access to research and innovative medications, the treatment of rare cancer becomes a bigger problem.

In the possible event of recurrence of disease, reasonable options include genomic tumor assessment followed by targeted therapy. Targeted therapy with tyrosine-kinase inhibitors like sunitinib could be considered based on others reports of clinical response, although the response observed occurred in patient with a tumor classified as clear cell sarcoma ${ }^{10}$. While the recently reported encouraging overall survival improvement in soft tissue sarcomas reached with olaratumab plus Doxorubicin, we cannot extrapolate such data to GNET because this population was not contemplated in the study ${ }^{11}$.

In this case report of metastatic GNET the patient received four cycles of neoadjuvant chemotherapy, using a doxorubicin/ifosfamide-based regimen following by complete surgical resection. Because he is alive after 26 months from diagnosis without evidence of recurrence, this strategy proves adequate for this patient and could be an option to similar cases. In this report, we can also observe an erratic pattern of uptake by PET-CT, suggesting that this method is not capable to exclude the presence/recurrence of GNET.

\section{REFERENCES}

1. Zambrano E, Reyes-Mugica M, Franchi A, Rosai J. An osteoclast-rich tumor of the gastrointestinal tract with features resembling clear cell sarcoma of soft parts: reports of 6 cases of a GIST simulator. International journal of surgical pathology. Apr 2003;11(2):75-81.

2. Huang W, Zhang $X$, Li D, et al. Osteoclast-rich tumor of the gastrointestinal tract with features resembling those of clear cell sarcoma of soft parts. Virchows Archiv : an international journal of pathology. Feb 2006;448(2):200-203.

3. Kong J, Li N, Wu S, Guo X, Gu C, Feng Z. Malignant gastrointestinal neuroectodermal tumor: A case report and review of the literature. Oncology letters. Dec 2014;8(6):2687-2690.

4. Pauwels P, Debiec-Rychter M, Sciot R, et al. Clear cell sarcoma of the stomach. Histopathology. Dec 2002;41(6):526-530.

5. Antonescu CR, Nafa K, Segal NH, Dal Cin P, Ladanyi M. EWS-CREB1: a recurrent variant fusion in clear cell sarcoma--association with gastrointestinal location and absence of melanocytic differentiation. Clinical cancer research : an official journal of the American Association for Cancer Research. Sep 15 2006;12(18):5356-5362.

6. Alyousef MJ, Alratroot JA, ElSharkawy T, et al. Malignant gastrointestinal neuroectodermal tumor: a case report and review of the literature. Diagnostic pathology. Mar 20 2017;12(1):29.

7. Kansal S, Rao S. Malignant Gastrointestinal Neuroectodermal Tumor: a Unique Rare Neoplasm. Indian journal of surgical oncology. Dec 2017;8(4):630-633.

8. Green C, Spagnolo DV, Robbins PD, Fermoyle S, Wong DD. Clear cell sarcoma of the gastrointestinal tract and malignant gastrointestinal neuroectodermal tumour: distinct or related entities? A review. Pathology. 2018 Aug;50(5):490-498.

9. Stockman DL, Miettinen M, Suster $S$, et al. Malignant gastrointestinal neuroectodermal tumor: clinicopathologic, immunohistochemical, ultrastructural, and molecular analysis of 16 cases with a reappraisal of clear cell sarcomalike tumors of the gastrointestinal tract. Am J Surg Pathol. 2012;36:857-68. 
10. Stacchiotti S, Grosso F, Negri T, Palassini E, Morosi C, Pilotti S, Gronchi A, Casali PG. Tumor response to sunitinib malate observed in clearcell sarcoma. Ann Oncol. 2010;21:1130-1.

11. Tap WD, Jones RL, Van Tine BA, Chmielowski $B$, Elias AD, Adkins $D$, Agulnik M, Cooney MM,
Livingston MB, Pennock G, Hameed MR, Shah GD, Qin A, Shahir A, Cronier DM, Ilaria R Jr, Conti I, Cosaert J, Schwartz GK. Olaratumab and doxorubicin versus doxorubicin alone for treatment of soft-tissue sarcoma: an open-label phase $1 \mathrm{~b}$ and randomised phase 2 trial. Lancet. 2016;388(10043):488. Epub 2016 Jun 9. 